\title{
The development of key training policies in England and Australia: a comparison
}

\author{
Andrew Smith* and Erica Smith \\ Charles Sturt University, Australia
}

Public policies on training are firmly rooted in the historical, political, economic and social context of their countries. This paper explores the acceptability of such policies to stakeholder groups including learners and employers, and its impact on policy take-up, viability and longevity. The paper uses a comparative analysis of developments in the English and Australian systems in three key areas, using elements of public policy theory, to explain the factors affecting stakeholder acceptance of training policies. The data was gathered through a series of interviews with stakeholders in England and Australia in 2005. The paper focuses on the role of employers and the importance of employer acceptance to the successful implementation of training policy. The paper finds that the successful implementation of training policies depends upon participation in the system by all the stakeholders. The successful implementation of qualifications and apprenticeship policies in Australia rests on a foundation of institutions that support neo-corporatist employer and union participation in policy-making as well as a public trust in past policies that seems to be lacking in England. The degree of employer involvement via neocorporatist mechanisms such as concertation has a highly significant impact on the success of national training policies.

\section{Introduction}

This paper examines the development of elements of training policy in Australia and England in the last two decades with a particular focus on three areas-the development of new vocational qualifications systems, entry level training and measures to increase employer investment in training. Developments in the vocational education and training (VET) systems in Australia and England have often mirrored one another as the two countries share many similarities and there is constant dialogue between policy-makers. However, the processes employed to formulate and implement VET policy during a period of considerable reform in both countries have often been very different. The paper examines these differences in approach to policy and suggests that policy success and

\footnotetext{
*Corresponding author. Charles Sturt University, Locked Bag 588, Wagga Wagga, NSW 2678, Australia. Email: asmith@csu.edu.au
} 
failure in both countries may be explained by a combination of institutional theory, pathdependency theory and the rise of neo-corporatism in Australia during the 1980s.

Institutional theory seeks to explain policy development as a stable process over time strongly influenced by the existing political and other institutions of the nation. The role of history plays an important role in modern institutionalist interpretations of policy development (Immergut, 1998). Historical institutionalism emphasizes the essential stability of policy which comes about as a result of the long-term nature of political institutions and political beliefs which create a policy consensus that is hard to break. In term of the VET sector, apprenticeships and qualifications are prime examples of educational institutions that have existed for a very long time in Australian society and play an important role in shaping future VET policy. A development of historical institutionalism has been the notion of path dependency (Pierson, 2000) in which policies are not only the result of the influence of political institutions but also create their own vested interests in society which ensure that policy development follows in the path of previous policies. Both these perspectives argue for a long-term stability in policy development rather than radical change. Naturally such institutionalist perspectives have difficulty in accounting for change and often resort to explanations that portray change as a reaction to some exogenous shocks (Beland, 2005).

A further refinement of institutionalism has been the notion of corporatism and more recently, neo-corporatism. In classical corporatism, policy-making is subject to the negotiations of elite peak bodies in society often representing business, Government and organized labour. Policy is fashioned to meet the needs of these major organized groups in society and compliance is enforced through these groups (Lehmbruch, 1979; Schmitter, 1979). Neo-corporatist arrangements involve the 'concertation' of major social partners but compliance is achieved through the democracy and persuasion amongst the groups involved rather than through coercion (Baccaro, 2003). Neo-corporatist theory has been used to explain the social dialogue arrangements that typify policy-making in many of the 'older' European Union members countries, especially in industrial relations.

Although the paper seeks to explore the role of all the major stakeholders in the process of formulation of training policies, it concentrates on the role of employers and the importance of employer commitment to policy implementation.

\section{Data sources}

While much of the paper is based on secondary sources such as Government policy documents, the arguments are augmented by primary data sources. These sources include interviews with senior policy and VET sector officials in both countries including officials from the lead agencies the Australian National Training Authority (ANTA) (now defunct and its functions subsumed under the Federal Department of Education, Science and Training) and its English counterparts the Sector Skills Development Agency (SSDA) and the Learning and Skills Development Agency (LSDA) (now defunct); and directors of skills councils and, in the Australian case, State Industry Training Advisory Boards, in both countries. These interviews were not undertaken specifically for the purposes of this paper but data have been extracted for the paper. In addition, recent experiences of both authors as 
managerial staff in bodies responsible for development of VET sector policy and practice (the National Centre for Vocational Education Research and a State Industry Training Advisory Board) in Australia have been included, in a form of participant observation (Wiersma, 1986, p. 235; Babbie, 1999, p. 264), as have data and insights from many research projects undertaken by the authors in the decade from 1995-2005.

\section{Training reform in Australia and England}

The reform of the vocational education and training system in Australia has been an ongoing process the late 1980s (Smith \& Keating, 2003). Training reform was spearheaded by the then Federal Labor Minister for Employment, Education and Training, John Dawkins, who had made the case for substantial reform of the VET system in a number of discussion papers released towards the end of the 1980s. The essential aims of what came to be known as the National Training Reform Agenda were to make the system more responsive to the needs of Australian industry and business and to create a national training system from the rather fragmented State-based systems that existed at the time. Employer bodies had been also calling for some time for major reforms to the VET system, particularly the creation of a national qualifications system so that qualifications gained in one State could be recognized in others. Under the terms of the Accord, which was a tax and wages agreement between the Australian Labor Party and the Australian Council of Trade Unions (ACTU), the union movement was also involved in Dawkins' proposed training reforms. The ACTU had also called for reforms to the training system in their blueprint for the reform of employment regulation in Australia (ACTU, 1988). Thus by 1990 a national consensus was emerging in favour of radical reform of the VET system.

As the Allen Consulting Group pointed out in their review of the training reform agenda (Allen Consulting Group, 1994), it was not a coherent program of VET reforms but rather a series of major reforms loosely connected to each other. A key element of the reform process was the implementation of competency-based training in the VET system. Over a period of about five years, each industry sector drew up national competency standards for all the occupations covered in its industry and all qualifications were re-designed in competency-based training form. A framework for the national recognition of qualifications was established together with a national qualifications system, the Australian Qualifications Framework. By the late 1990s, the competency-based qualifications system had evolved into a series of Training Packages which contained completed sets of competency standards and qualifications for all industry sectors (Smith \& Keating, 2003). The new national training market was also opened up to private providers with an increasing amount of funding in the VET sector being made available to private training providers. This broke the monopoly on publicly-funded training provision previously enjoyed by the public TAFE colleges in each State and allowed employers to choose which training provider would deliver certain types of training that they could purchase using public funding. By the late 1990s, about $25 \%$ of the training market was controlled by private training providers. A major change during the late years of the training reform agenda, from about 1995 onwards, was the rapid expansion of the apprenticeship and traineeship system, which is discussed below. The progress of the training reform agenda 
was overseen by a new joint State and commonwealth statutory authority, the Australian National Training Authority established in 1993 as a means of integrating increased Federal direction of the VET system with the requirements of the States and Territories to continue to administer the VET systems in their separate jurisdictions (Ryan, 2002). ANTA provided national co-ordination of many VET initiatives, including funding the national VET research effort, and a large dissemination and education function until it ceased operations in June 2005.

In England, the reforms to the VET system are often traced back to the original 'Great Debate' launched by then Prime Minister Jim Callaghan in 1976 which called for wider inputs into the development of the British education and training system, particularly in relation to the requirements of the labour market (Gleeson \& Keep, 2004). Radical reform of the training system, however, had to wait until, the election of the Conservative Thatcher Government of 1979-1990 and the New Training Initiative (NTI) of 1981. Prior to this period, the training system in England had been based on the provisions of the Industrial Training Act of 1964 and its subsequent revisions. The Industrial Training Act established a series of Industrial Training Boards supported by a levy grant system to organize and finance employer training. Vocational qualifications were administered by a plethora of accrediting bodies and qualifications authorities with the emphasis on apprenticeship qualifications and higher level business and commerce qualifications primarily delivered by further education colleges, the Higher National Certificate and the Higher National Diploma. Under the aegis of the NTI, the Industrial Training Boards were mostly abolished and replaced, in only some industries, by voluntary employer-led National Training Organisations. The levy grant systems were largely abolished and the training system deregulated. A key aim of the NTI was the reform of the complex vocational qualifications system with the introduction of national occupational standards for all industries and the conversion of qualifications into competency-based training format (Manpower Services Commission, 1981). The original target date for occupations to have national occupational standards (1985) was not, however, achieved (Raggatt \& Williams, 1999).

The New Training Initiative also introduced a new system of training for young people aimed at helping the youth unemployment problem caused by the recession of the early 1980s — the Youth Training Scheme (YTS). YTS developed from previous youth oriented labour market programs such as the Youth Opportunities Scheme (YOPS) and combined rudimentary training with a 12 month work experience program. In 1985, the de Ville review of vocational qualifications recommended the establishment of new system of competency-based National Vocational Qualifications (NVQs) to be overseen by the National Council on Vocational Qualifications. These qualifications were originally designed to provide a qualifications framework for the Youth Training Scheme. The reforms to the English training system were overseen and driven by the Manpower Services Commission (MSC) linked to the Department of Employment rather than the Department of Education.

In later years, the Conservative Government of John Major devolved the operation of the training system to local, employer-led bodies, the Training and Enterprise Councils (TECs). With the demise of the MSC and its successor bodies, the English Government created the TECs to supervise the funding of the VET system and to give local employers a 
major role in its operation. In line with the Conservative industrial relations philosophy, the TECs were strongly encouraged not to include any representatives from the union movement. Unions were systematically removed from the bodies overseeing the English VET system. Since the election of the Blair Government in 1997, the TECs have been replaced with local Learning and Skills Councils which are overseen by the national Learning and Skills Council and also include union as well as employer representatives. The Blair Government also introduced a new set of Sector Skills Councils to encourage the uptake of training by industry and to act as a liaison point between industry and Government on VET policy; these are coordinated by the Sector Skills Development Agency. However, as Keep (2006) points out, both the Learning and Skills Councils and the Sector Skills Councils are effectively under the direct control of the Department for Education and Skills.

\section{VET qualifications structures}

The development of the Australian Qualifications Framework in the early 1990s in Australia was an attempt to create a national system of VET from the fragmented State- and Territory-based systems. A major problem with the former State-based qualifications system had been the lack of portability between States caused by poor inter-State recognition systems. This had long been a source of grievance for employers and for unions whose members were often required to prove competence when they moved inter-State for employment. The Federal Government was keen to promote the development of a national system of qualifications as part of the process of creating a national VET system. Thus, the development of the Australian Qualifications Framework and its six levels of VET qualifications based on industry developed competency standards met the requirements of all the stakeholders in the Australian training reform process. The processes that led to the development of the Australian Qualifications Framework were handled on a tripartite basis. The development of competency standards for occupations was administered through committees including Government (State and Federal), employer and union representatives reporting to the National Training Board (later absorbed into ANTA), itself a tripartite body established to supervise the development of the new qualifications. In later years, despite the election of the Conservative Howard Government in 1996, the development of Training Packages was also handled on a similarly consultative basis. In the case of Training Packages, the longstanding tripartite Industry Training Advisory Bodies (ITABs) played the lead role in the development of the qualifications that formed the basis of the Training Packagesincluding union representatives and other experts as well as employers. Changes to policy and funding regimes have led to the progressive consolidation of national ITABs into ten Industry Skills Councils and the demise of many State ITABs.

Recent research has shown that the take up of Training Packages by Australian employers has been far greater than ANTA supposed (Smith et al., 2005). Evidence from this research suggests that almost half of large and medium-sized Australian enterprises are using Training Packages to provide nationally accredited training for their employees. For most, this involves working with a Registered Training Organization (RTO), although nearly 200 larger Australian enterprises have become RTOs themselves and can award qualifications directly to their employees. The enterprises are using Training Packages to 
provide qualifications and training for lower level occupational staff in their organizations, many of whom have not enjoyed access to this form of training in the past (Smith \& Smith, 2006). The research also shows that half of the enterprises using Training Packages are using the standards in the Training Packages to shape their approach to other human resource functions such as recruitment, selection and performance management (Smith \& Smith, 2006). It appears that Training Packages have been quite successful for Australian employers who are using the national qualifications system to upgrade the skills of their workforces. The adoption of Training Packages by enterprises has been considerably assisted by the availability of a range of sources of Government funding, particularly, but not only, for employers who place new and/or existing workers onto apprenticeships or traineeships.

The introduction of competency-based training and Training Packages has not been without controversy. There were many objections to competency-based training which arose partly from the nature of the early CBT qualifications, partly from poor implementation processes and partly from deep-rooted objections to competency-based training per se (Smith \& Keating, 2003). While industry competency standards have become more sophisticated and the attention to underpinning skills and knowledge in Training Packages has met many objections the system still has opponents (Smith, 2002).

In England, the development of NVQs has been more complex and more controversial. NVQs were originally conceived, as mentioned above, as providing a qualifications framework for the YTS. The development of the qualifications took longer than expected as the development of national occupational standards did not run to schedule (Franklin, 1997). The de Ville review of vocational qualifications that spearheaded the development of NVQs included employer representatives but was driven closely by the Manpower Services Commission (Raggatt \& Williams, 1999; Keep, 2006) with the result that NVQs were perceived as a Government-led initiative aimed at giving a basic qualification to youth in danger of unemployment. Moreover, NVQs were not devised as a system to replace the existing and complex array of vocational qualifications. The National Council for Vocational Qualifications (NCVQ) which oversaw the administration of NVQs sat alongside the traditional vocational qualifications base in England such as the City and Guilds of London and the Royal School of Arts. These other traditional vocational qualifications continued to exist and many employers and learners prefer to use them despite the introduction of NVQs and the exhortations of Government to adopt the new qualifications. Thus employer adoption of NVQs in England has thus been slow and reluctant in some industry areas, although in some areas it has been more enthusiastic.

Although similar in their conception, the development of NVQs in the England and Training Packages in Australia display some interesting differences. In Australia the more enthusiastic adoption of Training Packages has resulted from the rationale for the creation of the qualifications and from the inclusion of the key stakeholders in the process. The commitment of all the stakeholders to the creation of a new national system of vocational qualifications to replace the old State-based systems contrasts with the 'add on' nature of NVQs in the England which continue to compete with older established qualifications structures. Controversy has dogged both the English and Australian qualifications structures, especially as a result of their totally competency-based nature, which is 
not popular with all stakeholders, and the emphasis on the delivery of the qualifications in the workplace. However, the inclusion of all the major stakeholders in the development of the Australian Qualifications Framework and Training Packages created a sense of greater ownership of the qualifications amongst employers in Australia. In contrast, the Government driven nature of the review of vocational qualifications and the generally less consultative approach adopted created a degree of scepticism amongst stakeholders in the English VET system which persists to this day and has impeded the large-scale adoption of NVQs throughout the whole of industry.

\section{Apprenticeship}

Australian apprenticeship has considerable similarity with the traditional apprenticeship system in England. Apprenticeships are usually three or four years in duration and involve both on-the-job working and training at an employer's premises as well as formal study usually undertaken at a TAFE college. Traditional apprenticeship is confined to the traditional skilled trades areas which are mainly craft- and manufacturing-based. In the early 1990s, the numbers of apprentices recruited by Australian employers dropped significantly and remained at a low level until the late 1990s when the numbers of apprentices began to rise. This reflected both the impact of the 1990s recession as well as the decline in employment in traditional trades as the structure of the Australian economy moved towards service industries. In 1985, short, one- and two-year traineeships were introduced, in newer industry areas. Although Australian employers were slow to take up traineeships, the number of trainees rose quickly from 1995 as the Federal Government focused on marketing traineeships to employers and provided financial incentives for enterprises to employ trainees. Traineeships also expanded into many occupational areas that had not previously supported contracted training such as retail and tourism and hospitality (Robinson, 200I). In 1997 the traditional apprenticeship and the traineeships systems were brought together under the New Apprenticeship system (known since 2006 as Australian Apprenticeships) and numbers, especially in traineeships, escalated dramatically from about 120,000 in 1995 to over 400,000 by 2003 . These new areas tended to be where employment growth was occurring and the development of Training Packages for these occupational areas also stimulated growth. By 2003 the system had grown to 400,000 apprentices and trainees and has plateaued since then with 400,200 in training in June 2006 (NCVER, 2003, 2006). Twenty-eight percent of 2006 commencements were in traditional trades (NCVER, 2006). The numbers in Australian apprenticeships represents $3.5 \%$ of the working age population, one of the highest rates of contracted training in the developed world. Completion rates remain high for traditional apprenticeships at about $75 \%$ whilst traineeship completion rates have been lower at 55\% (Robinson, 2001). There have been a number of quality problems associated with the rapid growth of the apprenticeship and traineeship system in Australia (Schofield, 1999). These have been partially addressed by new policies but concerns about the quality of apprentice and particularly trainee training are still strong among some commentators and interest groups.

The English apprenticeship system has experienced more severe problems over the past 25 years. Almost decimated by the recession in the early 1980s and the devastation of 
major industries and enterprises that employed large numbers of apprentices, the institution almost disappeared in its recognized form. Modern apprenticeships were introduced in a number of new industry areas but failed to generate enthusiasm (Fuller \& Unwin, 2003), partly for reasons of status and partly because pay rates were low. Moreover the curriculum was seen to be inadequate because of the 'thin' nature of NVQs, and so additional and separate components of underpinning knowledge and key skills needed to be added, which many modern apprentices failed to complete. Modern apprenticeship has not been open to people aged over 25 (although in some industries this is changing) compared with Australia where there are no age barriers. Completion rates in England are well below 50\% in many industry areas (Spielhofer \& Sims, 2004) and absolute numbers of modern apprentices remain relatively low at around 130,000. Since April 2005 modern apprenticeships have been referred to simply as the apprenticeship system, and this may improve their status.

The differences between the Australian and English apprenticeship systems are quite marked. In Australia the preservation of traditional apprenticeships has been accompanied by a spectacular growth in traineeships so that a large number of occupations are now covered by the Australian apprenticeship system and a large number of employers have employed workers under this system as well as converting existing workers to apprentices or trainees. Although growth in Australian apprenticeships has slowed in the last few years, there is little doubt that the system has become firmly embedded as an entry-level training system for a large proportion of employers, although traineeships still suffer from a popular perception that they are in some way inferior (Smith, 2004). In England, by contrast, modern apprenticeships struggled to gain momentum. Low employer commitment in the England may be explained by a number of factors. In the 1980s, as discussed, the traditional apprenticeship system died out in England and when modern apprenticeship was launched in the 1990s, it emerged not from the traditional apprenticeship system but from the YTS and its successor programs. Thus, modern apprenticeships were strongly associated with labour market programs designed to combat youth unemployment rather than with high quality training programs.

In Australia, the traditional apprenticeship system survived. Although numbers of apprentices declined in the early 1990s, the strong links that apprenticeships in Australia enjoyed with the centralized industrial relations system helped to preserve the system intact (Gospel, 1994). The role of the industrial awards system in Australia helped to protect Australian apprenticeship from the steady decline that characterized the system in England. In England, the number of apprentices experienced sharp falls in late 1960s and early 1970s, the mid 1980s and again in the mid 1990s (Gospel, 1998). These falls in apprenticeship numbers were driven by the effects of economic recession as employers took the decision to cut training costs by cutting apprentice intakes. The disappearance of the Industrial Training Boards and the introduction of YTS in Britain, meant that there was no foundation on which to base a revival of apprenticeship with an upturn in the economic cycle. In Australia, the impact of economic downturn on the numbers of apprentices was reduced by the protection afforded the institution through the award system which enabled unions to insist on apprentice intakes by individual employers. So, although the numbers of apprentices in the traditional trades areas fell 
in the early 1990s, the falls were not as precipitous as in England and by the late 1990s, numbers were increasing.

At the same time as the numbers of traditional apprentices began to revive, traineeships also began to grow quickly in the mid 1990s as part of the Keating Government's Working Nation policy. Financial incentives from Federal and State Governments also played a major role in gaining employer commitment to the system (Smith et al., 2005), as did the creation and funding of intermediary bodies such as Group Training Organisations and New Apprenticeship Centres, rather than leaving the 'selling' of apprenticeships to training providers. However, despite the differences in success of apprenticeship systems in the countries, in both countries the move to an apprenticeship system that is more inclusive of newer industries and occupations has been resisted by some employer groups particularly those representing traditional craft and manufacturing trades.

\section{Stimulating employer training}

Countries in the developed world continue to grapple with the problem of raising employer investment in training (Keating et al., 2002). Most countries in the developed world have attempted to tackle the issue of employer investment in training and a number of different approaches have been identified (Smith \& Billett, 2004). Australia experimented with a levy like system in the early 1990s, known as the Training Guarantee Scheme. Organisations with payrolls in excess of $\$ 200,000$ were required under the Act to spend at least $1.5 \%$ of their payroll costs on eligible training or pay the shortfall to the Australian Taxation Office. Eligible training was defined as structured and employment-related but could be either on the job or off the job. The arguments that were advanced by the Federal Government in support of the introduction of the training guarantee scheme emphasized the need for a highly trained workforce in the restructuring of Australian industry that accompanied the reform of industrial relations under the award restructuring movement.

However, the training guarantee scheme proved unpopular with employers. Unlike other elements of the training reform agenda, the training guarantee was not subject to the same tripartite processes of consultation and implementation. The training guarantee was imposed by the Federal Government by statute-the Training Guarantee Act of 1990. Business groups reacted sharply to its introduction. A key criticism made by employer groups was the compliance costs of the training guarantee were excessive. Research by Velten (1990) showed that many enterprises considered that the costs of keeping records and ensuring that all eligible training was reported far outweighed the cost of paying the levy. Small businesses, in particular, expressed this view and there was a widespread belief that many small enterprises simply paid the levy rather than incur the costs associated with training. Another argument, not necessarily supported by evidence, was that the imposition of a minimum level of expenditure on training led some enterprises to reduce their training expenditure to this minimum level, particularly in the recessionary economic climate of the early 1990s. The training guarantee was also attacked for its focus on the quantity rather than the quality of training (Noone, 1991) and for instituting a regimebased on punishment for non-compliance rather than rewarding enterprises that increased their commitment to training. 
Some advocates of the training guarantee scheme were able to demonstrate some positive effects. Teicher (1995) identified three such effects. First, the requirement to record the training that took place in an enterprise led to greater level of accountability for managers in providing the requisite training for employees. Second, the availability of more information on training activities in the enterprise allowed managers to evaluate the effectiveness of training more closely. Finally, the training guarantee raised the status of training within enterprises, so that managers were able to take a more strategic approach to the linking of training activities with the business needs of the enterprise. However, little firm evidence has been produced that the training guarantee played a significant role in the increase in training expenditure from 1990 to 1993 (Smith \& Billett, 2004).

In the UK, the NTI and its related reforms to the VET system had swept away the Industrial Training Boards and the levy grant scheme that supported the system of financing employer training. In keeping with the voluntarist nature of the British VET system since NTI, there has been no attempt to revive the legislated levy on employers to encourage training. Instead, the emphasis for the improvement of training for existing workers has been focused on the Investors in People scheme. This has sat alongside Governmental exhortation for enterprises to invest more in their employee's development. The Investors in People (liP) program operates in a similar fashion to ISO accreditation in the area of quality management but with a specific focus on human resource development practices in enterprises. Those enterprises meeting the liP standard are permitted to use the liP kitemark for publicity. Although slow to gain ground, in recent years the liP program has expanded quite rapidly. Between 1999 and 2004 the number of enterprises recognized under liP more than doubled from 13,748 to 37,035 and the percentage of the workforce covered by the liP standard increased from $15.5 \%$ to $38 \%$ over the same period (www.iipuk.co.uk). However, coverage of liP is far from even across English industry. Recognition under the program is directly related to size and concentrated in certain industry sectors-particularly the public sector (Hoque et al., 2005). Moreover, there is a high degree of attrition from the scheme with many organizations committing to the scheme but failing to reach full recognition (Fernandez et al., 2005).

This skewed distribution of training amongst enterprises and has led commentators to remark that liP has been used to highlight those enterprises that already invest significantly in training rather than encourage firms that do not invest to undertake more training of their employees (Hoque, 2003). Amongst enterprises that are involved with liP, the scheme seems to have a beneficial impact on the nature and quality of the training they undertake. An evaluation of liP by the Institute of Employment Studies concluded that liP had succeeded in training practices and added demonstrable value to enterprises (Hillage \& Moralee, 1996). liP works in a similar fashion to, and uses the language of, ISO and other forms of quality accreditation. There is no doubt that UK enterprises have embraced liP in large numbers even thought it has yet to be shown the impact, if any, the program has had on increasing overall levels of investment in training.

The contrast of the Australian Training Guarantee scheme and the English liP scheme is more complex than the previous comparisons in this paper. The schemes are very different and have different objectives. Nevertheless, despite the criticisms made of the liP scheme's effectiveness in terms of improving English employer investments in training 
(Hoque et al., 2005), there is no doubt about its popularity with English employers compared to the deep unpopularity of the training guarantee with Australian employers. In England the voluntary nature of the scheme combined with the positive recognition that the liP kitemark brings employers has played a major role in its acceptability as a policy for improving training provision. In Australia, the training guarantee was imposed by law on employers without the consultative process that characterized other aspects of the training reform agenda. The continuing campaigning by business groups against the scheme finally persuaded the Federal Labor Government to trade off the training guarantee against other training reforms, especially the extension of apprenticeships and traineeships.

\section{Discussion}

Institutional theory allows us to compare the success and failure of VET policy in terms of the Governmental structures which play the major role in the formulation and implementation of these polices (Beland, 2005). From this perspective, English VET policy in the Thatcher period was firmly driven by Central Government initiative. England is administered by a centralized, unitary Government and under Thatcher, the power of centralized Government was used in many sectors to force through radical social and economic change. The NTI of $198 \mathrm{I}$ is an example of this highly centralized process of policy reform. The formerly tripartite and consultative system of the Industrial Training Boards supported by training levies was replaced by a more market oriented but Government controlled system. With few constraints on the operation of Central Government in England, the initiatives of a new and radical administration with a large electoral majority could be pushed through very quickly. Moreover, England's brief experiment with neocorporatism in the Social Compact of the 1970s was swept away in favour of Government initiated change. Unions were progressively cut out of Government policy-making in a number of areas by the Thatcher administration including in the VET arena. Employers also had little voice in the process. Although the Conservative Governments of the 1980s and 90 s were pro-business in their orientation, employer bodies did not play a central role in the formulation of new policies. Employer representative bodies in England have been historically weak with little ability to deliver the commitment of their members to new policy initiatives. Moreover, the general view of the Thatcher administration was that English business and management was as much in need of reform as other parts of English society after the Labour experiments with 'socialism'. Thus, although individual business people were involved in reviews of policy such as the de Ville review of vocational qualifications, they were not expected to represent the views of English industry but were rather selected for their individual expertise and outlook. The tripartism that had characterized policy-making in many areas of Government under the Social Compact in the 1970s disappeared in the 1980s. Even under the Blair Labour Government, as Keep (2006) has argued, the role of employers and unions is limited with most of the initiative coming from Central Government and new policies implemented through bodies which are essentially controlled by Government.

Reforms to the training system in England, therefore, proceeded with little attempt at consensus. Different parties may have been involved in some of the processes of VET 
policy formulation but the process was clearly strongly driven by the MSC and other Government agencies (Raggatt \& Williams, 1999; Keep, 2006). In particular, employers did not play a major role in the development of the new vocational qualifications and the modern apprenticeship systems. The failure of past policies such as the Youth Training Scheme also considerably affected employer perceptions of modern apprenticeship. Employer commitment to both of these new initiatives was, not surprisingly, limited. English employers have shown more interest in the liP scheme where the voluntary nature of the scheme and its marketing potential have been attractive. This also seems to be the case with the more recent Train to Gain initiative, the successor to the earlier Employer Training Pilots (Hillage et al., in press). Under Train to Gain, employers gain access to a Skills Broker who works with the employer to find ways of funding training for workers to gain numeracy and literacy training and NVQ Level 2 qualifications. Although this is another Government sponsored scheme, the emphasis is on control by the employer. This more autonomous role for the employer seems to be contributing to the scheme's success in attracting employers (Leitch, 2006).

In Australia, the Federal institutional context of Government produced quite different outcomes in VET policy. In Australia responsibility for VET is split between the States and Territories and the Commonwealth. The attempt by the Federal Labor Government in 1992 to take control of VET for the commonwealth met strong opposition from the States and resulted in the creation of ANTA as a joint State and Federal authority to oversee the strategic development of the sector (Ryan, 2002). Thus, in Australia, the Federal nature of the State meant that VET reform was predicated upon joint Federal State decision-making and consensus rather than direction from Central Government, although the recent disestablishment of ANTA and the assumption of many of its functions by the Federal Department of Education, Science and Training has led to greater centralism and was presumably undertaken for that purpose. At another level, Australia has a history of neocorporatist approaches to policy-making. This is particularly true of the industrial relations arena. Since the introduction of the centralized arbitration system of industrial relations at both State and Federal level in 1904, wages and conditions for workers have been set down in national awards negotiated through the industrial relations commission at a national and State level by Government, employers and unions. As a result, employers have developed effective associations and have become used to working closely with Government and unions to resolve industrial issues. The wide-ranging agreement between the Australian Labor Party and the ACTU known as the Accord in 1983 had a number of effects including on training policy. The centralized system has been undergoing a process of steady decentralization since that time through successive Government policies to emphasize workplace bargaining and individual agreements. However the Accord set the tone for the generally tri-partite (including employer associations) approach to policymaking adopted by the Hawke Labor administration of 1983-1991 which has had a lasting effect on VET policy-making (Cooney, 1997). It could be argued that many of the key initiatives that comprised the training reform agenda were devised by employer and unions through the industrial relations processes of the mid to late 1980s. The report of a tripartite mission to Europe, Australia Re-constructed (ACTU \& TDC, 1988), foreshadowed many of the later training reforms. The first phase of award re-structuring in the late $1980 \mathrm{~s}$ 
placed training and career pathways for employees at the centre of the newly rationalized awards. For the first time, training issues became a major industrial bargaining issue and provided the impetus for training reform, especially the development of new qualifications.

Combined with the necessity in the Federal system for consultation, the effect of the Accord was to include all relevant stakeholders in the policy networks that formulated and implemented the elements of the training reform agenda in the 1990s (Fenna, 2004). Employers played a major role in these networks and the committees which they formed. The strength of the Australian employer associations meant that employer acceptance of the new VET policies could be guaranteed by the employer representatives on the committees that implemented the training reforms. The interesting exception to this picture of employer compliance with the training reforms from our paper is the training guarantee scheme. As discussed earlier, the training guarantee was something of an exception in the training reform agenda. It was a policy formulated by the Government and imposed on employers by law without going through the normal consultative channels. Employer resistance was therefore guaranteed by the directive and centralized process of policy implementation that accompanied the training guarantee.

Unlike some other areas of public policy, training policies require active choices by institutional clients to participate. Potential learners must decide to apply for apprenticeships, to enrol in institutionally-based VET programs, or, in some cases, to request access to Government-funded programs available through their employers. Thus the discussion needs to examine the acceptability of VET policies to the general public who form the potential client group. Path dependency theory (Pierson, 2000), although normally used to describe developments at an institutional level, helps to explain different responses in England and Australia. As Fenna (2004, p. 136) puts it 'policy-making continues down (a previously-established) path because interests and assumptions become entrenched around (it)'. In England, current training policy began to be formulated during the early 1980s at a time of massive recession and high unemployment, and the early features of the policy such as YTS did not receive public support because they were seen as low-status 'schemes' designed to reduce unemployment figures. It could be argued that public perceptions were coloured by widespread resistance to the Thatcher Government in its early years and beliefs that some of the unemployment was generated deliberately by that Government to break the power of trade unions. In Australia, by contrast, although unemployment reached a similar peak at that time, there was less public mistrust of training policies, changes to which, in any case, were introduced at a slightly later stage. Mistrust of the renewed English modern apprenticeship system seems to persist, resulting in comparatively low numbers of apprentices compared with Australia. This is compounded by confusion among the English public about the availability and worth of qualifications, due to the initial positioning of NVQs alongside, rather than as a replacement for, earlier VET qualifications. The success of ANTA in driving through Training Package qualifications as the only recognized form of VET qualification (with minor exceptions) has prevented such confusion in the Australian public's mind, after an initial settling in period. Attempts to understand the way in which individuals engage with the VET system have in the past been based on human capital theory or have been focused on policies designed to improve 
access for equity groups rather than considering more deep-seated understandings by the public of VET offerings.

Acceptability and engagement with new VET policies clearly depends on a number of factors that have been touched upon in the analysis presented in this paper. Table I summarizes the key factors that impact on acceptability and engagement with VET policy by the key stakeholders-employers, unions and individuals.

The table indicates the importance of perceptions and attitudes about future gain, the importance of prior experiences, as well as the availability of opportunities and assistance.

\section{Conclusion}

For Governments, acceptability of and engagement with VET policies is critical to their success. The discussion section and Table $\mathrm{I}$ indicates that for employers and unions alike, acceptability and engagement with new VET policies depends on the extent of their involvement with policy-making and their perception of the added value of policy. In Australia the training guarantee scheme did not meet these criteria and was condemned by employers and, to lesser extent, unions. By contrast the creation of Training Package qualifications enjoyed a higher degree of acceptability. The existence of a coherent national VET system can also harness commitment. Thus in the UK the continuation of the traditional qualifications alongside NVQs made the VET system highly complex and deterred employers and individuals from using the new qualifications structures whereas in Australia Training Package qualifications superseded the older State-based qualifications structures and provided nationally recognized credentials, attractive to both individuals and employers alike. For employers, unions and individuals, acceptability and engagement depends on a strong perception of added value. In the UK, the lacklustre performance of modern apprenticeships reflects the low value placed on the qualifications by all parties. In Australia, new apprenticeships are increasingly being regarded as worthwhile programs, after an uncertain start. A perception of the value of new policy is also affected by perceptions of the value of the older policies from which they spring as suggested by path-dependency theory (Greener, 2005). Thus in the UK, modern apprenticeships and NVQs have been tainted by their association with the failed YOPS and YTS schemes of

Table I. Factors affecting whether major participating groups find training policies acceptable and are likely to engage with them

\begin{tabular}{|c|c|c|}
\hline Employers & Unions & Individuals \\
\hline Involvement in policy-making & Involvement in policy-making & Perception of added value of policy \\
\hline Perception of added value of policy & Perception of value for & to themselves \\
\hline Existence of a coherent national & members & Existence of a coherent national \\
\hline VET system & Existence of effective & VET system \\
\hline Existence of effective intermediary & intermediary bodies & Funding available to themselves \\
\hline bodies & Perceptions of past policies & Perceptions of past policies \\
\hline \multicolumn{3}{|l|}{ Perceptions of past policies } \\
\hline Funding to companies & & \\
\hline
\end{tabular}


the past. New apprenticeship in Australia has not suffered from these negative associations. Funding is always a critical issue. The availability of Government funding strongly influences the take up of new VET initiatives by employers and individuals. The subsidies that underpin the new apprenticeship system in Australia provide a good example of this. The existence of effective intermediary bodies such as ITABs or skills councils provide employers and unions with structures that allow the development of policy networks below the level of national policy-making forums that enable the key stakeholders to become closely involved in policy implementation as well as formulation. ITABs and Skills Councils in Australia seem to have been more successful historically in engaging stakeholders in shaping the new VET qualification structures at a grassroots level. Bodies designed to promote apprenticeships are another type of intermediary body that have been successful in Australia. But finally, the successful implementation of VET policies depends upon participation in the system by all the stakeholders-employers, unions and individuals. The comparison of policy formulation between England and Australia presented in this paper suggest that the successful implementation of qualifications and apprenticeship in Australia rested on a foundation of institutions that supported neocorporatist employer and union participation in policy-making as well as a public trust in past policies lacking in England.

\section{Notes on contributors}

Andrew Smith is Professor of Human Resource Management and Director of Research Development at Charles Sturt University. He was formerly General Manager, Research and Evaluation at the National Centre for Vocational Education Research. Andy has a Ph.D. in the area of enterprise training, which is his particular field of expertise. Andy has led a number of projects in the area of workplace training and organizational innovation and change. Andy is the author of numerous articles on aspects of employment and training and of the text, Training and development in Australia.

Erica Smith is Associate Professor of Vocational Education and Training at Charles Sturt University. Her non-academic experience includes personnel management, teaching in further education in both England and Australia, managing a private training organization and managing a State Industry Training Advisory Board. Her areas of research interest include apprenticeships, school to work transition, students' part-time work, competency based training and training policy. She has published widely and is the coauthor of the widely-referenced book on Australian training policy, From training reform to training packages.

\section{References}

Allen Consulting Group (1994) Successful reform: competitive skills for Australians and Australian enterprises (Melbourne, Allen Consulting Group).

Australian Council of Trade Unions \& Trade Development Council (1988) Australia re-constructed: report of the ACTU/TDA mission to Western Europe (Melbourne, ACTU). 
Babbie, E. (1999) The basics of social research (Belmont, Wadsworth).

Baccaro, L. (2003) What is alive and what is dead in the theory of corporatism, British Journal of Industrial Relations, $4 \mathrm{I}$ (4), 683-706.

Beland, D. (2005) Ideas and social policy: an institutionalist perspective, Social Policy and Administration, $39(I), I-18$.

Cooney, R. (1997) The contingencies of partnership: experiences form the training reform agenda in Australian manufacturing, Employee Relations, 24(3), 32I-334.

Fenna, A. (2004) Australian public policy (Sydney, Pearson).

Fernandez, R., Taylor, S. \& Bell, E. (2005) How long until, we get there? A survival analysis of the Investors in People initiative 1991-200I. SKOPE Research Paper No 56, University of Warwick.

Franklin, K. (1997) National vocational qualifications, Scottish vocational qualifications and competencebased education and training: from de Ville to Beaumont, Journal of Vocational Education and Training, 49(4), $5 \mathrm{II}-530$.

Gleeson, D. \& Keep, E. (2004) Voice without accountability: the changing relationship between employers, the State and education in England, Oxford Review of Education, 30(I), 37-63.

Gospel, H. (1994) The survival of apprenticeship training in Australia?, Journal of Industrial Relations, 36(I), 37-56.

Gospel, H. (1998) The revival of apprenticeship training in Britain?, British Journal of Industrial Relations, 36(3), 435-457.

Greener, I. (2005) The potential of path dependence in political studies, Politics, 25(I), 62-72.

Hillage, J. \& Moralee, J. (1996) The return on investors in people. Report 3 I4, Institute for Employment Studies, Brighton.

Hillage, J., Loukas, G., Newton, B. \& Tamkin, P. (in press) Employer training pilots: final evaluation report (London, Department for Education \& Skills).

Hoque, K. (2003) All in all, it's just another plaque on the wall: the incidence and impact of the Investors in People standard, Journal of Management Studies, 40(2), 543-57I.

Hoque, K., Taylor, S. \& Bell, E. (2005) Investors in People: market-led voluntarism in vocational education and training, British Journal of Industrial Relations, 43(I), 135-153.

Immergut, E. M. (1998) The theoretical core of the new institutionalism, Politics and Society, 26, 5-34.

Keep, E. (2006) State control of the English education and training system-playing with the biggest train set in the world, Journal of Vocational Education and Training, 58(I), 47-64.

Keating, J. Medrich, E., Volkoff, V. \& Perry, J. (2002) Comparative study of vocational education and training systems: national vocational education and training systems across three regions under pressure (Adelaide, NCVER).

Leitch, S. (2006) Prosperity for all in the global economy—worlds class skills (London, HMSO).

Lembruch, G. (1979) Liberal corporatism and party Government, in: P. Schmitter \& G. Lembruch (Eds) Trends towards corporatist intermediation (London, Sage), |47-183.

Manpower Services Commission (198I) A new training initiative (Sheffield, MSC).

National Centre for Vocational Education Research (1999) Statistics at a glance (Adelaide, NCVER).

National Centre for Vocational Education Research (2003) Australian vocational education and training statistics: apprentices and trainees, December 2003 (Adelaide, NCVER).

National Centre for Vocational Education Research (2006) Australian vocational education and training statistics: apprentices and trainees, June 2006 (Adelaide, NCVER).

Noone, L. (199I) Why I believe that the training guarantee is a great leap backwards rather than a small step in the right direction, Training and Development in Australia, 18, 19-20.

Pierson, P. (2000) Increasing returns, path dependence and the study of politics, American Political Science Review, 94, 25I-267.

Raggatt, P. \& Williams, S. (1999) Government, markets and vocational qualifications: an anatomy of policy (London, Falmer Press).

Robinson, C. (200I) Australian apprenticeships: facts, fiction and future (Adelaide, NCVER).

Ryan, R. (2002) Building a national vocational education a training system (South Africa, Institute of International Education, Flinders University). 
Schmitter, P. (1979) Still the century of corporatism?, in: P. Schmitter \& G. Lembruch (Eds) Trends towards corporatist intermediation (London, Sage), 7-49.

Schofield, K. (1999) Independent investigation into the quality of training in Queensland's traineeship system: final report: 2 July 1999 (Brisbane, Queensland department of Employment, Training and Industrial Relations).

Smith, A. \& Billett, S. (2004) Mechanisms for increasing employer involvement in training (Adelaide, National Centre for Vocational Education Research).

Smith, E. (2002) Training packages: debates around a new curriculum system, Issues in Educational Research, I2(I), 64-84.

Smith, E. (2004) Political construction of skill: the effects of policy changes in entry-level training in Australia on participation rates and on the perception of 'skill', paper presented at Learner and Practitioner: the Heart of the Matter: 7th Australian VET Research Association Conference, Canberra, 17-19 March.

Smith, E. \& Keating, J. (2003) From training reform to training packages (Tuggerah Lakes, NSW, Social Science Press).

Smith, E. \& Smith, A. (2006) How lower-level and vulnerable workers benefit from employers' engagement with the national qualification system in Australia, paper presented at the Socially Responsive, Socially Responsible Approaches to Employment and Work Conference, Australian Centre for Research in Employment and Work, Monash University Prato Centre, Tuscany, I-4 July.

Smith, E., Pickersgill, R., Smith, A. \& Rushbrook, P. (2005) Enterprises' commitment to nationally recognized training for existing workers (Adelaide, NCVER).

Spielhofer, T. \& Sims, D. (2004) Modern apprenticeships in the retail sector: stresses, strains and support, Journal of Vocational Education and Training, 56(4), 539-558.

Teicher, J. (1995) The training guarantee: a good idea gone wrong?, in: F. Ferrier \& C. Selby-Smith (Eds) The economics of education and training 1995 (Canberra, AGPS).

Velten, M. (1990) Training guarantee scheme: boon or burden?, Australian Accountant, August, 26-29.

Wiersma, W. (1986) Research methods in education: an introduction (Boston, Allyn \& Bacon). 